\title{
Determination of the parameters of the submerged cultivation of micromycete Trichoderma asperellum VKPM F-1323 for obtaining spore forms of culture

\author{
(C) Danis D. Ziganshin, ${ }^{1+}$ Anna A. Egorshina, ${ }^{2}$ Mikhail A. Lukyantsev, ${ }^{2}$ \\ Alexander S. Sirotkin, ${ }^{1}$ and Zlata A. Ostroumova ${ }^{1}$ \\ ${ }^{1}$ Department of industrial biotechnology. Faculty of Food Technology. Kazan National Research \\ Technological University. Karl Marx St., 68. Kazan, 420015. Republic of Tatarstan. Russia. \\ Phone: +7 (919) 689-20-83. E-mail: ziganshind@gmail.com \\ ${ }^{2}$ LLC "Organic Park". Vosstanya St., 100. Building, 45. Kazan, 420095. Republic of Tatarstan. Russia. \\ Phone: +7 (800) 500-26-45.
} Keywords: submerged cultivation, nutritional mediums, Trichoderma asperellum, biological substance.

\section{Abstract}

The basic physical parameters of the cultivation of micromycete Trichoderma asperellum VKPM F1323 are determined on complex nutrient media. The choice of the object of study was due to its antagonistic activity with attitude to many phytopathogenic fungi such as Ascochyta pisi, Cercospora beticola, Claviceps purpurea, Sclerotinia sclerotiorum, Alternaria alternata, Botrytis cinerea, Fusarium graminearum, Passalora fulva, Verticillum dahliae, as well as growth-stimulating activity with attitude to plants, suggesting a motivation for the use of Trichoderma asperellum VKPM F-1323 as the basis for biological products used in agriculture.

During the experiment, the nutrient medium composition $(\mathrm{g} / \mathrm{l})$ was used: molasses -20 , yeast extract 7, $\mathrm{NaNO}_{3}-2, \mathrm{~K}_{2} \mathrm{HPO}_{4}-1, \mathrm{KCl}-0.5, \mathrm{MgSO}_{4}-0.5, \mathrm{FeSO}_{4}-0.01$. Before sterilization, the $\mathrm{pH}$ was adjusted to 7.5. Cultivation was carried out at a temperature of $27^{\circ} \mathrm{C}$ with constant stirring and aeration in autoclaved laboratory fermenters with a working volume of 21 . The cultivation of micromycete in a liquid nutrient medium was chosen in connection with the rapid progress of the process. In addition, unlike solid-phase cultivation, the deep one allows accumulating in the finished product form numerous secondary metabolites with antagonistic activity against phytopathogens, as well as growth-stimulating activity with attitude to plants.

In the work, the values of mixing speed, aeration intensity, and initial $\mathrm{pH}$ of the medium are determined, which determine the maximum productivity of the process according to the conidia concentration (titer) of the studied culture. During the cultivation process, the $\mathrm{pH}$ level was monitored without maintaining it during the process, since it is known that a change in $\mathrm{pH}$ values characterizes the course of the cultivation process with the formation of spore forms, and the initial $\mathrm{pH}$ value is an important factor in the conidia formation of Trichoderma fungi. It is shown that during cultivation for 72 hours the maximum concentration of conidia is achieved for a stirring speed of $700 \mathrm{rpm}$, without reflective baffles (chippers) in the design of the fermenter, aeration intensity of $0.251 / 1$ of medium $\times$ min and the initial $\mathrm{pH}$ of the nutrient medium 7.0 . Subject to the above conditions, the concentration of conidia is $1.35 \pm 0.09$ conidia $/ \mathrm{ml}$.

\section{References}

[1] V.A. Zakharenko. The market of pesticides in Russia and its development prospects. Plant protection and quarantine. 2014. No.11. P.3-6. (russian)

[2] Hayes J., Laws E. (1991) Handbook of Pesticide Toxicology, vol. 1, Academic Press, San Diego. P.1576.

[3] Lopez O., Fernandez-Bolanos J.G., Gil M.V. (2005) New trends in pest control: the search for greener insecticides. Green Chemistry 7 (6). P.431-442.

[4] N.S. Zakharchenko et al. The effect of associative microorganisms on the resistance of tomatoes to phytopathogens in vitro and in vivo. Bulletin of Tula State University. Natural Sciences. 2010. No.1. P.175-185. (russian)

[5] I.T. Korol. Biological plant protection. Minsk: Urajay. 2000. P.414.

Kazan. The Republic of Tatarstan. Russia.

(C) Butlerov Communications. 2019. Vol.59. No.9. 
[6] The state catalog of pesticides and agrochemicals approved for use in the Russian Federation. Moscow: Ministry of Agriculture of the Russian Federation. 2013. (russian)

[7] S.D. Said. Spore Production by Biocontrol Agent Trichoderma harzianum in Submerged Fermentation: Effect of Agitation and Aeration. Jurnal Rekayasa Kimia \& Lingkungan. 2009. Vol.6. No.2. P.71-76.

[8] R.E. Cardoza et al. Secondary metabolites produced by Trichoderma and their importance in the biocontrol process. Microorganism for Industrial Enzymes and Biocontrol. 2005. P.1-22.

[9] D.D. Ziganshin, A.S. Sirotkin. Features of deep and surface cultivation of Trichoderma fungi for biologics based on mushroom cells. Bulletin of Kazan Technological University. 2017. Vol.20. No.10. P. 155-158. (russian)

[10] A. Singh et al. Optimal physical parameters for growth of Trichoderma species at varying $\mathrm{pH}$, temperature and agitation. Virol Mycol. 2014. Vol.3. No.1. P.1-7.

[11] R. Lejeune, G.V. Baron. Effect of agitation on growth and enzyme production of Trichoderma reesei in batch fermentation. Applied microbiology and biotechnology. 1995. Vol.43. No.2. P.249-258.

[12] Patel N. et al. Growth of Trichoderma reesei RUT C-30 in stirred tank and reciprocating plate bioreactors. Process Biochemistry. 2009. Vol.44. No.10. P.1164-1171.

[13] D. Moore, G.D. Robson, A.P.J. Trinci. 21st century guidebook to fungi with CD. Cambridge University Press. 2011.

[14] RF patent No. 2016131536, 08/02/2016. The strain of the fungus Trichoderma asperellum to obtain a biological product of complex action for crop production. Patent of Russia №2634415. 2017. Bull. No. 30. Egorshina A.A., Lukyantsev M.A., Ziganshin D.D. [et al.].

[15] RF patent No. 2016151237, 12/26/2016. A method of obtaining a biological product for processing plants. Patent of Russia No. 2658430. 2018. Bull. No.18. Egorshina A.A., Lukyantsev M.A., Ziganshin D.D. [et al.]

[16] The effect of various carbon sources on conid formation of Trichoderma asperellum OPF-19 micromycete under deep cultivation conditions. Ziganshin D.D., et al. Materials of the International Congress "Biotechnology: State and Development Prospects" February 20-22, 2017. Vol.2. P.115-117. (russian) 